\title{
Effect of Covid 19 lockdown on the lifestyle and dietary diversity of women handloom workers
}

\author{
A. Aiswarya, M.Sc. *, D. Bhagya, M.Sc., PhD \\ Dept. of Home Science, St. Joseph's College for Women, Alappuzha, 688001, Kerala, India
}

\section{A R T I C L E I N F O}

\section{Keywords:}

COVID 19

Dietary diversity

Handloom

Nutrition profile

Women

\begin{abstract}
A B S T R A C T
Background: Covid-19 lockdown has influenced the lifestyle of handloom women as weaving is the only mean of earnings for them. The nutrition profile of working women is a vital part of their general health as they have more chances of dietary deficiencies; in addition they face various safety related problems at workplace. Working conditions and household responsibilities complicate role conflict leading to stress that in turn affect nutrition and health status.

Material and methods: Purposive sampling method was used to collect data from 100 samples of women handloom workers between the ages of 30-60 years from Kanhirode Weaver's Co-operative Society, Kannur, Kerala, India. Personal interview method was used for data collection. The interview schedule included occupational health profile, anthropometric, physical activity and food frequency assessment. Dietary diversity questionnaire was used to assess the levels and adequacy of dietary diversity. Depression Anxiety Stress Scale (DASS) was used to assess psychological well-being among the samples.

Results: COVID-19 lockdown downgraded the life style of majority (90.7\%) of women workers. Majority of samples were with mean age $46.74 \pm 5.73$ years and height of $1.52 \pm 0.10 \mathrm{~m}$ respectively. Out of 100,63 samples noticed a weight change from which majority $(71.4 \%)$ noticed an increase in their body weight. The mean weight before lockdown was $54.100 \pm 7.603 \mathrm{Kg}$ and after lockdown $55.020 \pm 8.013 \mathrm{Kg}$. The mean BMI before lockdown was $23.232 \pm 2.866$ and after lockdown BMI slightly increased to $23.572 \pm 2.928$. Lockdown introduced a significant reduction in percentage of consumption of pulses ( $3.7 \pm 1.2 \mathrm{~g})$, fish ( $4.1 \pm 0.5 \mathrm{~g})$, chicken $(2.0 \pm 0.6 \mathrm{~g})$, meat $(1.4 \pm 0.6 \mathrm{~g})$ and milk products $(4.6 \pm 1.05 \mathrm{ml})$. Most of the subsamples were not meeting the calories $(2063.3 \pm 166.9 \mathrm{Kcal})$, fat $(20.6 \pm 4.3 \mathrm{~g})$ and micronutrients such as vitamin A $(761.3 \pm 180.3 \mathrm{mg})$, vitamin C $(61.2 \pm 15.9 \mathrm{mg})$ and calcium $(963.3 \pm 183.9 \mathrm{mg})$ requirements which indicate the incomplete dietary diversity.

Conclusion: The nutrition profile of women handloom workers was negatively influenced by the COVID-19 pandemic.
\end{abstract}

\section{Introduction}

Coronavirus has impacted Universe altogether through strict lockdowns and limitations. The lockdown limited people from stepping out of their homes with an unexpected disruption of their everyday routine; their financial status as well as overall household functions was accompanied by major uncertainties. The handloom industry is still one of the important unorganized activities in the country. In accordance with the Fourth All India Handloom Census 2019-20, the field employs over 35 lakh workers. ${ }^{1}$ Approximately, two-third of them is women workers and most of them are in socially backward groups. More than
$60 \%$ earn fewer than 5000 per month. According to Federation of Indian Chambers of Commerce and Industry (FICCI) handloom sector is one of the biggest cottage industries with inside the country and still produces about $17 \%$ of the whole cloth manufacturing in India. ${ }^{2,3}$ This unexpected economic damage in handloom sector will certainly have an impact on the employees also. Their lifestyle has been influenced by this Covid-19 lockdown as weaving is the only mean of earnings for them. Health is a vital or crucial part of worker's life. No need to mention that a healthy worker will efficiently work for improving his or her working organization and can promote healthy families too. But sometimes the workers face different workplace problems due to unsafe working

\footnotetext{
* Corresponding author.

E-mail addresses: aiswaryadinesha12@gmail.com (A. Aiswarya), bhagyasjcw@gmail.com (D. Bhagya).
} 
environment. Health is fundamental as it forms the foundation for running and operating family activities. Use of unsafe chemicals, dangerous machines, heat generating systems, dust, dirt and high noise levels are the major causes of work associated health problems. ${ }^{4} \mathrm{~A}$ sufficient amount of physical activity (more than $30 \mathrm{~min}$ of physical activity, more than 5 days a week) and a healthy diet play an essential role in the prevention of diseases such as heart diseases, cancer, obesity, osteoporosis, and psychological ailments. Women are more likely to be afflicted by nutritional deficiencies than men. Mal-nutrition in women in addition is aggravated through repeated pregnancies and lactation. ${ }^{5}$ It is important to take extra care of women than men who are at risk of malnutrition. Nevertheless, the nutritional needs and reproductive health of the women should not be justified by the aspect of their maternity only, but also by their overall well-being and health. ${ }^{6}$ There is a tendency in the society to consume mainly the cheap food items that are easily available and different classes in the society consume food differently. Low class households tries to consume a small number of food groups like cereals mainly the most available and low price rice and wheat, vegetables and fish and the intake of meat and egg is limited among them. When comparing with this group, high class families consume more food items and include fruits and meat products in their diet. ${ }^{7}$ Stress at work is a common problem for all employees, especially women. A combined factor contributes to workplace stress such as job conditions, problem of balancing work and family issues. In this study it was observed that the majority of women's family care was affected due to the crash between household activities and their work. Women had little time to relax, to give time for personal health problems, and to attend social engagements. ${ }^{8}$ Stress and family problems are positively linked in working women. ${ }^{9}$

Dietary diversity is one of the ways to improve the quality of living by identifying where the nutrients are lacking by which immunity and nutritional status can be boosted. Working women, especially handloom workers don't get time to concentrate on their nutrition, diet and physical activity. This study gives main focus on the approach of women handloom workers towards dietary diversity and their nutritional status. Even though there are many works related to handloom industry, studies related to lifestyle and nutrition profile of handloom workers are limited which further increases the study significance. The aim of the present study is to identify the occupational health problems, to assess the nutritional profile of handloom working women and associated anthropometric changes before and during the pandemic lockdown, to compare the duration of sleeping hours of working women before and during lockdown and to evaluate the occupational stress levels and effect of COVID 19 on psychological well-being of handloom working women.

\section{Methods}

\subsection{Sample and design}

The sample size estimation was done considering the Covid 19 restrictions at the weaving society and also since the purposive sampling doesn't have a specific sample size estimation method a total of 100 samples of women handloom workers between the ages of 30-60 years who gave saturated information was selected from traditional handloom field.

\subsection{Inclusion and exclusion criteria}

Women workers who operate handloom and charka in the weaving units were included in the study. Those who were pregnant and those with physical disabilities were excluded from sampling.

\subsection{Data collection tools}

Personal interview method was used for data collection after getting prior consent from the general secretary of Co-operative Society and the workers. The interview schedule included occupational health profile, anthropometric assessment, assessment of physical activity, dietary diversity, food frequency assessment and assessment of psychological well-being.

\subsubsection{Occupational health profile}

Occupational health problems faced by the handloom workers such as respiratory problems, pain in joints and muscles, cardiovascular problems, digestive problems, eye problems, ENT problems, skin diseases and other health problems were enquired using a checklist created after several study reviews.

\subsubsection{Anthropometric assessment}

The height of the sample was measured using stadiometer. The standing height was taken with the subject wearing no shoes, standing erect with heels together. Weight was measured using weighing machine. The samples were asked to monitor weights before and after lockdown. The samples have been following their monthly weight check-up in the weaving units itself so it was easy to obtain their weight before lockdown. After 7 months of lockdown they were asked to monitor their body weight changes for the research purpose. Anthropometric assessment done in a person can detect the grade of malnutrition and assess progression towards nourishment. ${ }^{10}$ BMI can be calculated by dividing an individual's weight in kilogram by the square of the person's height in meters. The measurements in centimeters (100 $\mathrm{cm}=1 \mathrm{~m}$ ) were converted to meter. ${ }^{11}$ BMI before and after lockdown were calculated and classified according to Asia Pacific BMI classification (2017) where people with BMI less than $18.5 \mathrm{~kg} / \mathrm{m}^{2}$ were considered as underweight and 18.5 to $22.9 \mathrm{~kg} / \mathrm{m}^{2}$ were grouped as normal. Workers with BMI between 23 and $24.9 \mathrm{~kg} / \mathrm{m}^{2}$ had been grouped as overweight and people with BMI greater than $25 \mathrm{~kg} / \mathrm{m}^{2}$ were grouped as obese.

\subsubsection{Assessment of physical activity}

Questions associated with type of physical activity involved in work as well as physical activity during lockdown were included. Sleeping pattern before (working days and holidays) and during lockdown were also included.

\subsubsection{Dietary diversity assessment}

Women's Dietary Diversity Score (WDDS) at individual level was used for collection of dietary diversity information, based on the nine food groups proposed by Food and Nutrition Technical Assistance (FANTA) ${ }^{12}$ The WDDS reveals the micronutrient adequacy of the diet. The individual who consume less than 3 food groups was considered to have low dietary diversity and those who consume 4-5 food groups and more than 6 food groups were considered to be in medium dietary diversity and high dietary diversity.

\subsubsection{4 h recall method}

Collected detailed information about the respondent's past $24 \mathrm{~h}$ consumption of all foods and beverages, most commonly, from midnight to midnight the previous day. ${ }^{13}$ The nutrient intake was calculated among 50 subsamples.

\subsubsection{Assessment of food frequency}

The food frequency questionnaire observed how often or frequently an individual eats certain foods, and the portion size. ${ }^{11}$ The common food groups based on food practices were listed in the interview schedule where the samples were asked to mark the frequency against each food intake.

\subsubsection{Assessment of psychological well-being}

Depression Anxiety Stress Scale (DASS) was used to assess the psychological well-being. The DASS is a 42 item, a valid and reliable tool 
that measures the three negative states of emotions such as depression, anxiety and stress. To complete the DASS, the client has to choose any responses of $0-3$ to the statements in each of the three subscales. The score 3 indicates high levels of the psychological state. ${ }^{14}$ The DASS is divided into 3 subsets of questions for depression, anxiety and stress which includes 14 questions for each.

\subsection{Statistical analysis of data}

After the data collection it was analyzed and subjected to statistical analysis using SPSS (Statistical Package for Social Sciences) version 26. Normality distribution test was done and the data was found to follow normal distribution, descriptive and inferential analysis was computed. The descriptive statistics included measures of central tendency of continuous variables age, height, weight, nutrient intake, food frequency expressed in mean and standard deviation. The frequency of occupational problems, change in food consumption before and during lockdown, were reported in frequencies as percentage. Inferential statistics of Chi-square test and paired sample $t$-test were used to test the association between Covid-19 lockdown with lifestyle and weight, association of sleeping hours before and during lockdown.

\section{Result}

\subsection{Occupational health problems faced by female handloom weavers}

Out of 100 samples majority (61\%) of them were suffering from occupational morbidities and $39 \%$ were not having any occupational health problems. Out of 61 workers who suffer from occupational health problems, majority (93.4\%) have pain in joints and muscle. It can be due to the continuous movement of their hands and legs to operate the loom and also due to long hours of sitting. The majority of female workers had musculoskeletal disorders, which included pain in their hands, arms, limbs, shoulder, and neck. Several studies have also reported that women's health is usually affected by backache and joint pain. The workers who have to depend completely on handloom work for their income mainly faces the problems of pain, and has to tolerate a lot of strain for their sustenance. Women are more susceptible to illness than men as they involve in both domestic duties and jobs in the workplace.

Respiratory problems were observed in $19.7 \%$ workers, which can be resulted from the loom dust in the weaving units. Spinning involve twisting the cotton thread together to form yarn. Increased prevalence of respiratory symptoms has been related to inhalation of cotton dust. ${ }^{15}$ Organic dye exposure causes symptoms such as chest tightness, which is most noticeable when returning to work following a break, and altered pulmonary functions. ${ }^{16}$ Workers suffering from skin diseases were $11.5 \%$ that can be linked with various processes involved in weaving such as dyeing, spinning and packing. ${ }^{17}$ Occupational morbidities like dermatitis, allergic conjunctivitis have been observed among workers who produce or handle reactive dyes.

Samples having occupational eye problems were $11.5 \%$, only $3.3 \%$ and $3.2 \%$ of workers were suffering from ENT problems and headache respectively which may be caused by long hours of concentrated work ${ }^{4}$ (Fig. 1). Workers who worked for less than $7 \mathrm{~h}$ reported difficulty with eyesight. High noise levels present in the Indian work environment influence the workers well-being and cause ill health and symptoms such as headache and hearing problems. With the absence of engineered noise control, these occupational exposures causes impaired hearing. ${ }^{18}$

\subsection{Anthropometric changes before and during the pandemic lockdown}

COVID-19 lockdown influenced 75\% workers lifestyle and downgraded the life style of majority (90.7\%) of women workers (Fig. 2). Majority (63\%) of samples noticed significant changes in their body weight. Out of 63 samples, majority (71.4\%) noticed an increase in their body weight $(55.020 \pm 8.013 \mathrm{Kg}$ ) with calculated t value -3.570 and $\mathrm{p}$ value $<0.05$ and it indicates a significant change in weight before and after lockdown. The mean value of BMI before lockdown was $23.232 \pm$ 2.866 and the mean value after lockdown was $23.572 \pm 2.928$ with calculated t value -3.178 and $p$ value $<0.05$; a significant change in BMI before and after lockdown (Table 1). The lockdown brought a notable reduction in the percent of normal (48\%) and underweight (1\%) while the frequency of overweight (28\%) and obesity (23\%) increased with Pearson Chi-square value 136.258 and $p$ value less than 0.001 which indicate a significant association between weight change and lockdown due to COVID-19 (Table 2). Rise in weight gain, overweight, and obesity in adults and the elderly in quarantine during pandemic lockdown are linked to dietary and eating behavior changes. ${ }^{19}$

Majority (70\%) of samples spent most of their time at work sitting; doing weaving only. $25 \%$ handloom workers spent most of their time at work standing or walking whereas only $5 \%$ involved in work with definite physical effort including handling of heavy objects like dyeing and drying of yarns. During lockdown majority (77\%) were involved in moderate physical activities like carrying light loads. Only $17 \%$ samples were involved in vigorous activities like heavy lifting, digging and 51\% samples involved in walking. Majority (58.8\%) was involved in vigorous activities for less than $1 \mathrm{~h}, 49.4 \%$ of women were involved in moderate physical activities for $1-2 \mathrm{~h}$ and (90.2\%) spent less than $1 \mathrm{~h}$ on walking.

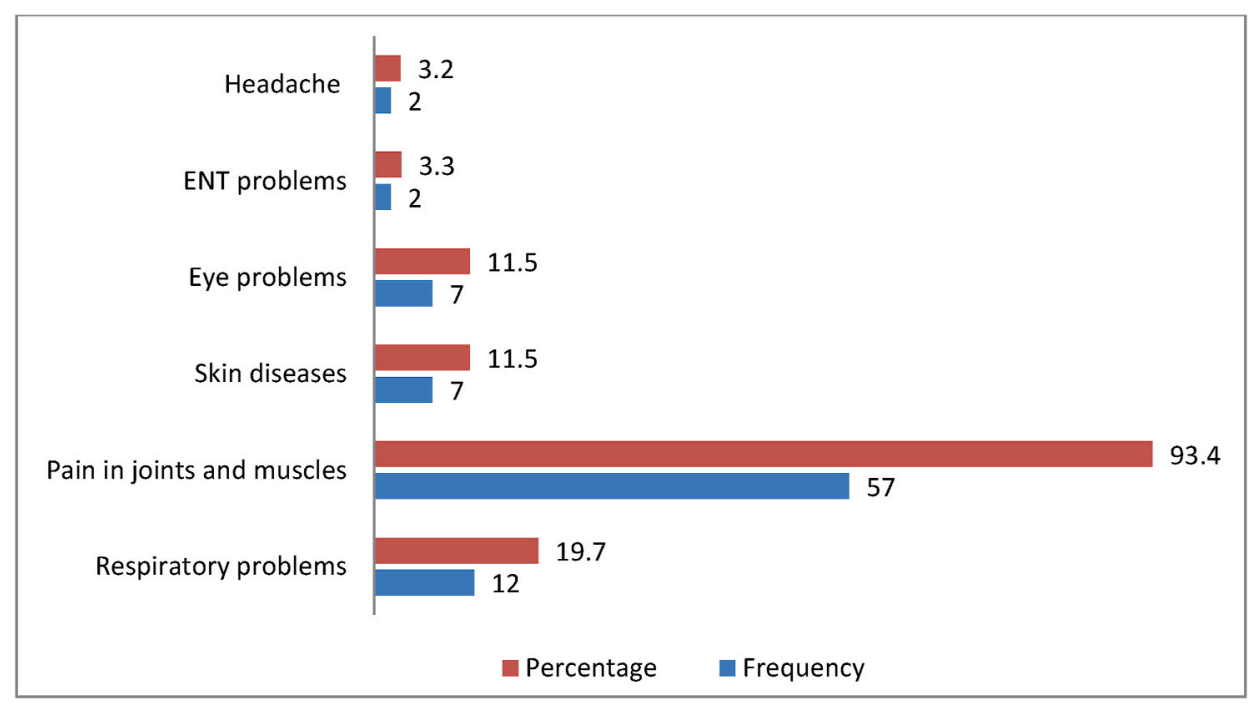

Fig. 1. Frequency of occupational morbidities. 


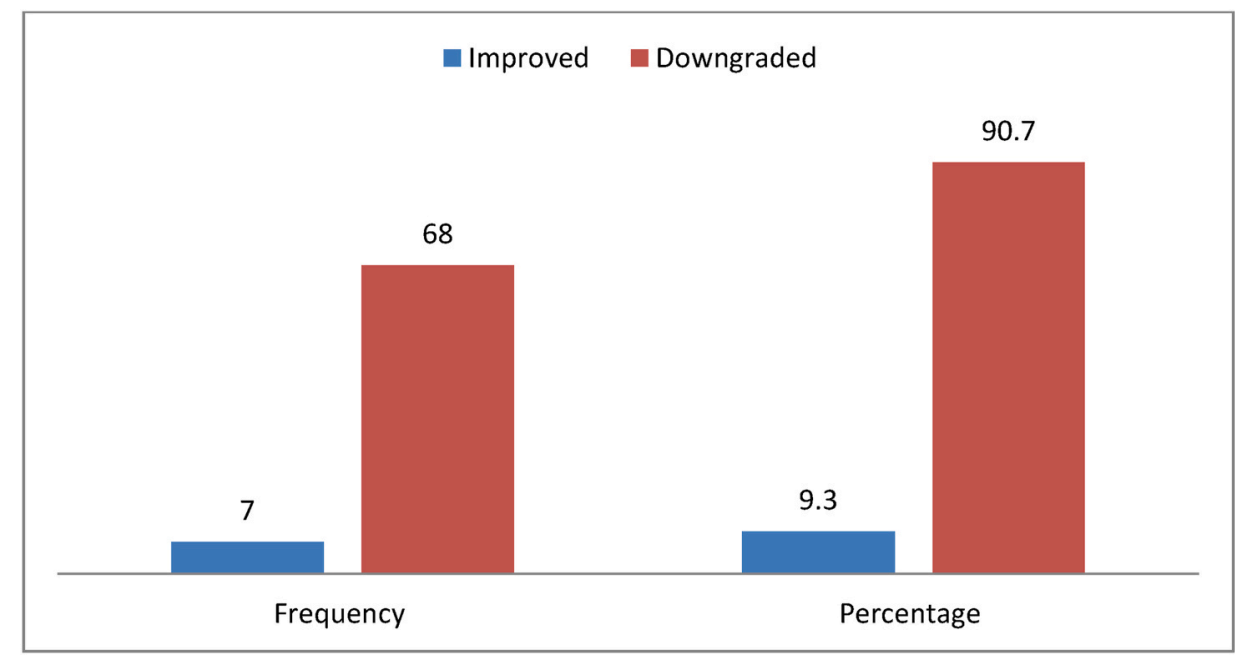

Fig. 2. Influence of COVID-19 lockdown on lifestyle.

Table 1

Influence of lockdown on body weight.

\begin{tabular}{|c|c|c|c|c|c|c|c|}
\hline \multirow[t]{2}{*}{ Variable } & \multicolumn{2}{|c|}{ Before Lockdown } & \multicolumn{2}{|c|}{ After Lockdown } & \multirow[t]{2}{*}{ Paired Mean Differences } & \multirow[t]{2}{*}{$\mathrm{t}$ value } & \multirow[t]{2}{*}{$P$ value } \\
\hline & Mean & Standard Deviation & Mean & Standard Deviation & & & \\
\hline Weight (Kg) & 54.100 & 7.603 & 55.020 & 8.013 & -0.920 & -3.570 & 0.001 \\
\hline BMI $\left(\mathrm{Kg} / \mathrm{m}^{2}\right)$ & 23.232 & 2.866 & 23.572 & 2.928 & -0.340 & -3.178 & 0.002 \\
\hline
\end{tabular}

Paired Samples $t$-Test; significant at $\mathrm{P}$ value $<0.05$.

Table 2

Association between weight change and covid-19 lockdown.

\begin{tabular}{|c|c|c|c|c|c|c|c|c|}
\hline \multicolumn{2}{|c|}{ Parameter } & \multicolumn{4}{|c|}{ After lockdown } & \multirow[t]{2}{*}{ Total (n) } & \multirow{2}{*}{$\begin{array}{l}\text { Pearson Chi- } \\
\text { Square }\end{array}$} & \multirow[t]{2}{*}{$P$ value } \\
\hline & & Normal (n or \%) & Obese (n or \%) & $\begin{array}{c}\text { Over Weight (n or } \\
\%)\end{array}$ & $\begin{array}{l}\text { Under Weight (n or } \\
\%)\end{array}$ & & & \\
\hline Before & Normal (n) (\%) & $40(78.4 \%)$ & $0(0 \%)$ & $11(21.6 \%)$ & $0(0 \%)$ & 51 & 136.258 & $<0.001$ \\
\hline \multirow{4}{*}{ lockdown } & Obese (n) (\%) & $1(5 \%)$ & $18(90 \%)$ & $1(5 \%)$ & $0(0 \%)$ & 20 & & \\
\hline & Over weight (n) (\%) & $6(22.2 \%)$ & $5(18.5 \%)$ & $16(59.3 \%)$ & $0(0 \%)$ & 27 & & \\
\hline & $\begin{array}{c}\text { Under weight (n) } \\
(\%)\end{array}$ & $1(50 \%)$ & $0(0 \%)$ & $0(0 \%)$ & $1(50 \%)$ & 2 & & \\
\hline & $1(n)$ & 48 & 23 & 28 & 1 & 100 & & \\
\hline
\end{tabular}

Chi-Square Tests; significant at $\mathrm{P}$ value $<0.001$.

Majority (56\%) of women spent more than $4 \mathrm{~h}$ for sitting during lockdown which indicates that lockdown increased the sedentary behavior of the workers life.

\subsection{Duration of sleeping hours before and during lockdown}

The time spent for sleeping for 7-9 h got increased to $85 \%$ whereas $15 \%$ samples slept less than $7 \mathrm{~h}$ when compared to sleep duration before lockdown with calculated chi square value 15.033 and $p$ value $<0.001$ on working days (before lockdown) and after lockdown and chi-square value 72.874 with $p$ value $<0.001$ in comparison with sleeping hours on holidays (before lockdown) and after lockdown which present a significant association between sleeping hours and lockdown (Table 3). The level of physical activity and exercise duration was reduced and an increase in weight gain among the participants was observed. ${ }^{20} \mathrm{~A}$ prolonged stay at home during the crisis could result in increased inactivity and sedentary lifestyle which in turn lead to imbalance in psychological state. ${ }^{21}$ People who live an active lifestyle are especially vulnerable to such disturbances. ${ }^{22}$ People's sleeping and waking habits had shifted dramatically by the second week of the lockdown, started to go to bed and wake up late, and spend higher time in bed. ${ }^{23}$

\subsection{Changes associated with nutritional profile}

Majority (53\%) of samples hasn't changed the quantity of eating during lockdown. In case of $20 \%$ samples the quantity of eating got reduced and $27 \%$ reported to have improvement in quantity. In general the habit of overeating; an overall change in eating and dietary habits than usual might occur. Frequency of snacking and meal was found to be increased. ${ }^{20}$

\subsubsection{Food frequency of samples}

All (100\%) samples consumed cereals daily before and during lockdown it being the main staple of Keralites. Before lockdown $22 \%$ women consumed pulses daily while $60 \%$ consumed pulses 3 to 4 times a week and $18 \% 1$ to 2 times a week respectively; the daily consumption of pulses reduced to $15 \%$ during lockdown and $76 \%$ samples consumed 3 to 4 times a week and $9 \%$ consumed 1 to 2 times a week. Majority (95\%) of samples consumed vegetables daily before lockdown, while five percent consumed 3 to 4 times a week and during lockdown the daily consumption of vegetables got increased by $1 \%$ (96\%) and $3 \%$ consumed vegetables 3-4 days per week and only $1 \% 1$ to 2 times per week. Before lockdown in case of fruit consumption majority (52\%) of 
Table 3

Difference in sleep duration before and during lockdown.

\begin{tabular}{|c|c|c|c|c|c|}
\hline \multirow{2}{*}{$\begin{array}{l}\text { Duration of sleep } \\
\text { (Before lockdown- } \\
\text { Working days) }\end{array}$} & \multicolumn{2}{|c|}{$\begin{array}{l}\text { Hours of sleep (During } \\
\text { lockdown) }\end{array}$} & \multirow[t]{2}{*}{$\begin{array}{l}\text { Total } \\
\text { (n) }\end{array}$} & \multirow[t]{2}{*}{$\begin{array}{l}\text { Pearson } \\
\text { Chi-Square }\end{array}$} & \multirow[t]{2}{*}{$P$ value } \\
\hline & $\begin{array}{l}<7 \text { hrs } / \\
\text { night (n } \\
\text { or } \%)\end{array}$ & $\begin{array}{l}\text { 7-9hrs/ } \\
\text { night (n or } \\
\% \text { ) }\end{array}$ & & & \\
\hline $\begin{array}{l}<7 \text { hrs } / \text { night (n } \\
\text { or } \%)\end{array}$ & $\begin{array}{l}15(27.8 \\
\%)\end{array}$ & $\begin{array}{l}39(72.2 \\
\%)\end{array}$ & 54 & 15.033 & $<0.001$ \\
\hline $\begin{array}{l}\text { 7-9hrs/night (n } \\
\text { or } \% \text { ) }\end{array}$ & $0(0.0 \%)$ & $\begin{array}{l}46(100 \\
\%)\end{array}$ & 46 & & \\
\hline Total (n) & 15 & 85 & 100 & & \\
\hline $\begin{array}{l}\text { Duration of sleep } \\
\text { (Before }\end{array}$ & \multicolumn{2}{|c|}{$\begin{array}{l}\text { Hours of sleep (During } \\
\text { lockdown) }\end{array}$} & $\begin{array}{l}\text { Total } \\
\text { (n) }\end{array}$ & $\begin{array}{l}\text { Pearson } \\
\text { Chi- }\end{array}$ & $\begin{array}{l}\mathbf{P} \\
\text { value }\end{array}$ \\
\hline $\begin{array}{l}\text { lockdown- } \\
\text { holidays) }\end{array}$ & $\begin{array}{l}<7 \text { hrs / } \\
\text { night (n } \\
\text { or } \%)\end{array}$ & $\begin{array}{l}7-9 h r s / \\
\text { night (n } \\
\text { or } \%)\end{array}$ & & Square & \\
\hline $\begin{array}{l}<7 \text { hrs } / \text { night (n } \\
\text { or } \%)\end{array}$ & $\begin{array}{l}14(82.4 \\
\%)\end{array}$ & $3(17.6 \%)$ & 17 & 72.874 & $<0.001$ \\
\hline $\begin{array}{l}\text { 7-9hrs/night (n } \\
\text { or } \% \text { ) }\end{array}$ & $1(1.2 \%)$ & $\begin{array}{l}82(98.8 \\
\%)\end{array}$ & 83 & & \\
\hline Total (n) & 15 & 85 & 100 & & \\
\hline
\end{tabular}

Chi-Square Tests; significant at $\mathrm{P}$ value $<0.001$.

samples consumed 1 to 2 times per week and only $8 \%$ took fruits daily whereas during lockdown the daily consumption of fruits got reduced by $4 \%$ but majority (60\%) started to consume fruits 3 to 4 times. Due to their perceived immune-boosting effect, some studies recorded increased intake of fruits, herbal tonics, vitamins, ginger, garlic, and multivitamins among participants. ${ }^{24}$ When the intake of food items like chicken, fish, meat are compared, there is a notable reduction in their consumption during lockdown; might be due to their unavailability or strict restriction to step out of homes and a small percent of respondents were vegetarian. In case of egg and milk no significant changes were seen (Table 4). Such confinements can cause difficulty in purchasing food items and there may be shortages of some foods. COVID-19 lockdown have significant influence on food frequency; a significant reduction in percentage of daily consumption of pulses $(3.7 \pm 1.2 \mathrm{~g})$, fish $(4.1 \pm 0.5 \mathrm{~g})$, chicken $(2.0 \pm 0.6 \mathrm{~g})$, meat $(1.4 \pm 0.6 \mathrm{~g})$ and milk products $(4.6 \pm 1.05 \mathrm{ml})$ (Table 5).

\subsubsection{4 h nutrient intake}

Most of the subsamples were not meeting the Calorie $(2063.3 \pm$ $166.9 \mathrm{Kcal})$, Fat $(20.6 \pm 4.3 \mathrm{~g})$, micronutrients such as Vitamin A (761.3 $\pm 180.3 \mathrm{mg})$, Vitamin C $(61.2 \pm 15.9 \mathrm{mg})$ and Calcium $(963.3 \pm 183.9$ $\mathrm{mg}$ ) requirements which indicate the incomplete dietary diversity (Table 6).
Table 5

Change in food frequency during lockdown.

\begin{tabular}{|c|c|c|}
\hline \multirow[t]{2}{*}{ Food items } & $\begin{array}{l}\text { Before lockdown } \\
\text { (Frequency) (\%) }\end{array}$ & $\begin{array}{l}\text { During lockdown } \\
\text { (Frequency) (\%) }\end{array}$ \\
\hline & Mean $( \pm$ S.D $)$ & Mean $( \pm$ S.D) \\
\hline $\begin{array}{l}\text { Cereals and cereal } \\
\text { products }\end{array}$ & $5.0 \pm 0.0$ & $5.0 \pm 0.0$ \\
\hline Vegetables & $4.9 \pm 0.2$ & $4.9 \pm 0.2$ \\
\hline $\begin{array}{l}\text { Milk and milk } \\
\text { products }\end{array}$ & $4.7 \pm 1.10$ & $4.6 \pm 1.05$ \\
\hline Fish & $4.3 \pm 1.2$ & $4.1 \pm 0.5$ \\
\hline Pulses & $4.04 \pm 0.6$ & $3.7 \pm 1.2$ \\
\hline Fruits & $3.5 \pm 0.7$ & $3.6 \pm 0.7$ \\
\hline $\begin{array}{c}\text { Green leafy } \\
\text { vegetables }\end{array}$ & $2.9 \pm 0.8$ & $2.9 \pm 0.9$ \\
\hline Egg & $3.0 \pm 0.9$ & $2.9 \pm 0.8$ \\
\hline Chicken & $2.2 \pm 0.5$ & $2.0 \pm 0.6$ \\
\hline Meat & $1.6 \pm 0.6$ & $1.4 \pm 0.6$ \\
\hline
\end{tabular}

Note. Abbreviation SD - Standard Deviation.

Table 6

$24 \mathrm{~h}$ nutrient intake of samples.

\begin{tabular}{ccc}
\hline Nutrients & $\begin{array}{c}\text { Mean nutrient intake } \\
( \pm \text { SD) }\end{array}$ & $\begin{array}{c}\text { Recommended Dietary Allowance } \\
(\text { RDA })\end{array}$ \\
\hline Energy (Kcal) & $2063.3 \pm 166.9$ & 2130 \\
Protein (g) & $60.2 \pm 14.9$ & 45.7 \\
Fat (g) & $20.6 \pm 4.3$ & 25 \\
Vitamin A & $761.3 \pm 180.3$ & 840 \\
( $\mu$ g) & & \\
Calcium (mg) & $963.3 \pm 183.9$ & 1000 \\
Vitamin C & $61.2 \pm 15.9$ & 65 \\
$(\mathbf{m g})$ & & \\
\hline
\end{tabular}

RDA Source: ICMR, 2020.

Note. Abbreviation: SD - Standard Deviation.

\subsubsection{Dietary diversity of samples}

It was noticed that the samples were giving importance to cereals and majority (58\%) were having medium dietary diversity score (Score 4 or 5) due to the consumption of 4-5 food groups whereas $33 \%$ were having high dietary diversity (Score $>6$ ) who consume more than 6 food groups and only $9 \%$ were found to have low dietary diversity score (Score $\leq 3$ ) because of consuming three or less than 3 food groups (Fig. 3). When considering the dietary diversity in detail it was noticed that majority of samples were only giving importance to cereals (rice, wheat), pulses and legumes and other vegetables such as onion, tomato, and ladies finger. They weren't conscious or bothered about dietary diversity and nutritional status. The consumption of vitamin A rich vegetables, tubers and fruits (pumpkin, carrot and mango), dark green leafy vegetables, organ meat was once or twice in a month. A cross-sectional analysis of working women in Thailand found that about half of the women had inadequate

Table 4

Food frequency before and during lockdown.

\begin{tabular}{|c|c|c|c|c|c|c|c|c|c|c|}
\hline \multirow[t]{2}{*}{ Food items } & \multicolumn{5}{|c|}{ Before lockdown } & \multicolumn{5}{|c|}{ During lockdown } \\
\hline & $\begin{array}{l}\text { Daily } \\
\text { (n) }\end{array}$ & $\begin{array}{l}\text { 3-4 times/ } \\
\text { week (n) }\end{array}$ & $\begin{array}{l}\text { 1-2 time/ } \\
\text { week (n) }\end{array}$ & $\begin{array}{l}\text { Once in a } \\
\text { month (n) }\end{array}$ & $\begin{array}{l}\text { Never } \\
\text { (n) }\end{array}$ & $\begin{array}{l}\text { Daily } \\
\text { (n) }\end{array}$ & $\begin{array}{l}\text { 3-4 times/ } \\
\text { week (n) }\end{array}$ & $\begin{array}{l}\text { 1-2 time/ } \\
\text { week (n) }\end{array}$ & $\begin{array}{l}\text { Once in a } \\
\text { month (n) }\end{array}$ & $\begin{array}{l}\text { Never } \\
\text { (n) }\end{array}$ \\
\hline Cereals & 100 & 0 & 0 & 0 & 0 & 100 & 0 & 0 & 0 & 0 \\
\hline Pulses & 22 & 60 & 18 & 0 & 0 & 15 & 76 & 9 & 0 & 0 \\
\hline Vegetables & 95 & 5 & 0 & 0 & 0 & 96 & 3 & 1 & 0 & 0 \\
\hline $\begin{array}{l}\text { Green leafy } \\
\text { vegetables }\end{array}$ & 4 & 17 & 50 & 29 & 0 & 4 & 14 & 55 & 24 & 3 \\
\hline Fruits & 8 & 35 & 52 & 5 & 0 & 4 & 60 & 32 & 3 & 1 \\
\hline Meat & 0 & 0 & 4 & 48 & 48 & 0 & 0 & 6 & 26 & 68 \\
\hline Chicken & 0 & 0 & 26 & 63 & 11 & 0 & 0 & 25 & 53 & 22 \\
\hline Egg & 2 & 24 & 51 & 13 & 10 & 3 & 24 & 52 & 10 & 11 \\
\hline Fish & 60 & 26 & 4 & 2 & 8 & 30 & 42 & 12 & 5 & 11 \\
\hline $\begin{array}{l}\text { Milk and milk } \\
\text { products }\end{array}$ & 88 & 3 & 3 & 0 & 6 & 88 & 3 & 2 & 0 & 7 \\
\hline
\end{tabular}




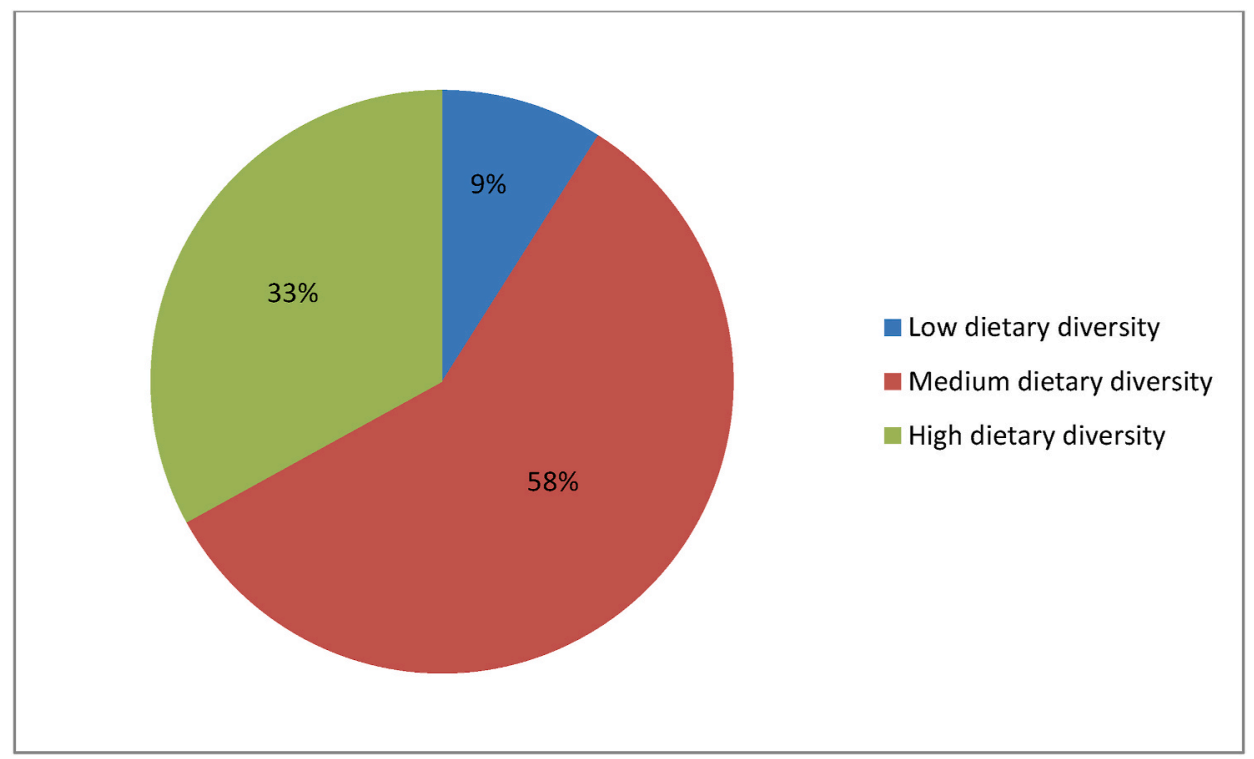

Fig. 3. Dietary diversity of the samples.

energy intake, while protein intake was generally adequate. However, the majority of the study participants had insufficient calcium (and to a lesser extent iron) intake. ${ }^{25}$ Based on the national average food consumption, it was found that the "weaving households were taking wheat, meat and egg less than the national average consumption while intake of rice, vegetables, potato, pulses, milk and fish were more than the national average consumption". ${ }^{26}$

\subsection{Occupational stress levels and effect of COVID 19 on psychological well-being}

Women workers who fall in 41-50 years have more prevalence of depression, even though majority (41\%) was normal. Handloom workers of age group 41-50 years have more prevalence of anxiety and stress. When compared to unmarried and widow workers, married women were more suffering from mild, moderate and severe forms of depression, anxiety and stress. Since stronger family relationships appear to be beneficial in mitigating mental health consequences, the individuals who stayed back with their families during lockdown were less likely noticed to have mental health issues, especially in females. ${ }^{27}$ Family responsibilities, job insecurity, workplace culture and high demand of job performance are the reasons for stress among employed women. ${ }^{28}$

\section{Discussion}

After getting prior consent from the general secretary of the Cooperative Society personal interview method was conducted among 100 samples of women handloom workers between the ages of 30-60 years following purposive sampling method. Those who were pregnant and those with physical disabilities were excluded from sampling. The interview schedule included occupational health profile, anthropometric assessment, assessment of physical activity, dietary diversity, food frequency assessment and assessment of psychological well-being.

COVID-19 lockdown downgraded the life style of majority (90.7\%) of women workers. Majority of respondents were with mean age 46.74 \pm 5.73 years with mean height of $1.52 \pm 0.10 \mathrm{~m}$. Majority (63\%) of samples noticed significant change in their body weight; Out of 63 samples, majority $(71.4 \%)$ noticed an increase in their body weight; mean value of weight before lockdown $54.100 \pm 7.603 \mathrm{Kg}$ and after lockdown $55.020 \pm 8.013 \mathrm{Kg}$. The mean value of BMI before lockdown was $23.232 \pm 2.866$ and after lockdown it slightly increased to 23.572 \pm 2.928.Lockdown introduced a significant reduction in percentage of consumption of pulses $(3.7 \pm 1.2 \mathrm{~g})$, fish $(4.1 \pm 0.5 \mathrm{~g})$, chicken $(2.0 \pm$ $0.6 \mathrm{~g})$, meat $(1.4 \pm 0.6 \mathrm{~g})$ and milk products $(4.6 \pm 1.05 \mathrm{ml})$. Most of the subsamples were not meeting the calorie $(2063.3 \pm 166.9 \mathrm{Kcal})$, Fat $(20.6 \pm 4.3 \mathrm{~g})$, micronutrients such as Vitamin A $(761.3 \pm 180.3 \mathrm{mg})$, Vitamin C $(61.2 \pm 15.9 \mathrm{mg})$ and Calcium $(963.3 \pm 183.9 \mathrm{mg})$ requirements which indicate the incomplete dietary diversity. Majority (61\%) of the samples were suffering from occupational morbidities such as pain in joints and muscles, respiratory problems, skin problems, ENT and eye related problems. The time spent for sleeping for 7-9 h got increased to $85 \%$ whereas $15 \%$ samples slept less than $7 \mathrm{~h}$ when compared to sleep duration before lockdown with calculated chi square value 15.033 and $\mathrm{p}$ value $<0.001$ on working days (before lockdown) and after lockdown and chi-square value 72.874 with $\mathrm{p}$ value $<0.001$ in comparison with sleeping hours on holidays (before lockdown). Women workers who fall in 41-50 years have more prevalence of depression, even though majority (41\%) was normal. Handloom workers of age group 41-50 years have more prevalence of anxiety and stress. When compared to unmarried and widow workers, married women were more suffering from mild, moderate and severe forms of depression, anxiety and stress.

\section{Conclusion}

It can be inferred that changes in the lifestyle and nutrition profile during COVID-19 influenced the quality of life of women handloom workers. Their life style was affected as the pandemic limited them from stepping out of home and weaving was the only mean of income for them. From daily moderate working habits they were shifted to a sudden sedentary lifestyle, reduced physical activities and increased sleeping hours with unchanged meal consumption which contributed to their weight changes. In spite of these while considering their daily life before and during pandemic their attitude toward food was very disappointing, it is like what they get will eat, as there was not much time to concentrate on nutrition and dietary diversity and hence majority of them were in medium dietary diversity category.

\section{Funding}

This research did not receive any specific grant from funding agencies in the public, commercial, or not-for-profit sectors. 


\section{Declaration of competing interest}

None.

\section{Acknowledgements}

Deep gratitude for the co-operation and patience rendered by the general secretary and all the women workers of Kanhirode Weavers Cooperative Society.

Grateful to the management of St Joseph's College for Women Alappuzha, Kerala, India affiliated to University of Kerala for the valuable co-operation extended during this study.

\section{References}

1 Ministry of Textiles. Fourth All India Handloom Census 2019-20; 2019. http://ha ndlooms.nic.in/writereaddata/3736.pdf.

2 FICCI. Indian handloom industry. 2019:7-44.

3 Das A, Sutradhar R. Handloom Weavers and lockdown in sualkuchi. Economic\&Political WEEKLY. 2020;LV(39):23-25.

4 Koiri P. Occupational health problems of the handloom workers : a cross sectional study of Sualkuchi , Assam , Northeast India. Clinical Epidemiology and Global Health. 2020;8(4):1264-1271. https://doi.org/10.1016/j.cegh.2020.04.025.

5 Bhoyar AM. Effect of area on nutritional status of working and nonworking women. Food Science Research Journal. 2014;5(2):81-85. https://doi.org/10.15740/has/fsrj/ 5.2/81-85.

6 Majied S, Shafiq S. Nutritional status of working women in Kashmir ( Rural and urban population ). International Journal Of Science and Research. 2016;5(11): $1472-1476$.

7 Rabbani A. Household food security in Bangladesh: going beyond poverty measures. Bangladesh Development Studies. 2014;XXXVII(1 \& 2):103-125.

8 Saha TK, Dasgupta A, Butt A, Chattopadhyay O. Health status of workers engaged in the small-scale garment industry: how healthy are they? Indian Journal of Community Medicine. 2010:79-82.

9 Dhanabhakyam M, Malarvizhi J. Work-family conflict and work stress among married working women in public and private sector organizations. International Research Journal of Business and Management. 2014;VII(10).

10 Cashin K, Oot L. Guide to anthropometry: a practical tool for program planners, managers, and implementers. Food and Nutrition Technical Assistance III Project (FANTA)/FHI. 2018;360:7.

11 FANTA. Nutrition assessment, counseling, and support (NACS): a user's guide-module 2: nutrition assessment and classification, version 2. Nutrition Assessment, Counseling, and Support (NACS). 2016;2:1-12.

12 Swindale A, Bilinsky P. Household Dietary Diversity Score (HDDS) for Measurement of Household Food Access: Indicator Guide, Version 2. Food and Nutrition Technical Assistance Project. Washington, D.C: Academy for Educational Development; 2006.
13 Castell GS, Serra-Majem L, Ribas-Barba L. What and how much do we eat? 24-hour dietary recall method. Nutricion Hospitalaria. 2015;31(3):46-48. https://doi.org/ 10.3305/nh.2015.31.sup3.8750.

14 Laura Gale L. Anxiety and depression Assessment : using the depression anxiety stress scales. Social Work Practice \& Skill. 2015:1-5.

15 Paudyal P, Semple S, Niven R, Tavernier G, Ayres JG. Exposure to dust and endotoxin in textile processing workers. The Annals of Occupational Hygiene. 2011;55(4): 403-409. https://doi.org/10.1093/annhyg/meq084.

16 Bansal M, Yadav RK. Occupational health hazards and awareness of occupational safety among workers of textile dyeing industries in Jaipur, India. International Journal of Environment, Science and Technology. 2016;2(2):30-38. Suresh Gyan Vihar University.

17 Lellis B, Fávaro-polonio CZ, Pamphile JA, Polonio JC. Effects of textile dyes on health and the environment and bioremediation potential of living organisms. Biotechnology Research\&Innovation. 2019;3:275-290. https://doi.org/10.1016/j. biori.2019.09.001.

18 Nag A, Vyas H, Nag P. Occupational health scenario of Indian informal sector. Industrial Health. 2016;54:377-385.

19 Sidor A, Rzymski P. Dietary choices and habits during COVID-19 Lockdown : experience from Poland. Nutrients. 2020;12:1-13.

20 Rawat D, Dixit V, Gulati S, Gulati S, Gulati A. Impact of COVID-19 outbreak on lifestyle behaviour : a review of studies published in India. Diabetes \& Metabolic Syndrome: Clinical Research \& Reviews Journal. 2021;15:331-336.

21 Chen P, Mao L, Nassis GP, Harmer P, Ainsworth BE, Li F. Coronavirus disease ( COVID-19 ): the need to maintain regular physical activity while taking precautions. Journal of Sport and Health Science. 2020;9(2):103-104. https://doi.org/10.1016/j. jshs.2020.02.001.

22 Martinez-de-Quel O, Suarezz-Iglesias D, Lopez-Flores M, Perez CA. Physical activity, dietary habits and sleep quality before and during COVID-19 lockdown : a longitudinal study. Appetite. 2021;158(105019):1-6. https://doi.org/10.1016/j. appet.2020.105019.

23 Cellini N, Canale N, Mioni G, Costa S. Changes in sleep pattern , sense of time and digital media use during COVID-19 lockdown in Italy. Journal of Sleep Research. 2020:1-5. https://doi.org/10.1111/jsr.13074.

24 Paul G, Sharma S, Singh G, et al. Assessment of knowledge gaps and perceptions about COVID-19 among health care workers and general public-national crosssectional study. Journal of Anaesthesiology, Clinical Pharmacology. 2020;36(3): $337-344$.

25 Inoguchi NM, Shimbo S, Zhang Z, et al. Nutrient intake of working women in Bangkok, Thailand, as studied by total food duplicate method. European Journal of Clinical Nutrition. 2000;54:187-194.

26 Rahman MA, Noman SMMH. Poverty and food security analysis of handloom weaver households in a selected area of Bangladesh. Journal of Bangladesh Agricultural University. 2019;17(1):80-85. https://doi.org/10.3329/jbau.v17i1.40667.

27 Alfawaz HA, Wani K, Aljumah AA, et al. Psychological well-being during COVID-19 lockdown : insights from a Saudi state university's academic community. Journal of King Saud University-Science. 2021;33(1):101-262. https://doi.org/10.1016/j. jksus.2020.101262.

28 Rajasekhar D, Sasikala B. An impact of stress management on employed women, Health and Medical Care Services. Claims on National Resources. 2013;13(4). 